\title{
Efforts to Increase Teacher Motivation and Performance Through Supervision of Head Master SD Negeri 150 Seluma
}

\section{Upaya Meningkatkan Motivasi dan Kinerja Guru Melalui Supervisi Kepala Sekolah di SD Negeri 150 Seluma}

\author{
Budi Harsono \\ SD Negeri 150 Seluma \\ E-mail: budi harsono.bkl@gmail.com
}

Diterima 26 Maret 2018, Direvisi 26 April 2018, Disetujui Publikasi 30 Juni 2018

\begin{abstract}
Target of research of action go to school this is to improve performance and motivation learn SDN 150 Seluma pass activity of headmaster supervision. Its research type is research of school action. Activity of this research consist of step planning of action, execution of action, observation, and refleksi. Technique analyse data use technique of obeservasi. Instrumen observation the used is appliance assessment of ability of teacher in the form of instrument assessment of teacher performance and motivation. Result of research show finding that headmaster supervision of SDN 150 Seluma school year 2016 / 2017 can improve motivation work cycle of I equal to $29 \%$ becoming $86 \%$ mounting $57 \%$ and performance learn SDN 150 Seluma in cycle of I from $43 \%$ mounting to become $86 \%$ or there is make-up of equal to $43 \%$
\end{abstract}

Keywords: headmaster supervision, teacher motivation, teacher perform

\begin{abstract}
Abstrak
Tujuan penelitian tindakan sekolah ini adalah untuk meningkatkan motivasi dan kinerja guru SDN 150 Seluma melalui kegiatan supervise kepal sekolah. Jenis penelitiannya adalah penelitian tindakan sekolah. Kegiatan penelitian ini terdiri atas tahapan perencanaan tindakan, pelaksanaan tindakan, observasi, dan refleksi.Teknik analisis data menggunakan teknik obeservasi.Instrumen observasi yang digunakan adalah alat penilaian kemampuan guru (APKG) berupa Instrument penilaian motivasi dan kinerja guru. Hasil penelitian menunjukkan temuan bahwa supervisi kepala sekolah SDN 150 Seluma tahun pelajaran 2016/2017 mampu meningkatkan motivasi kerja siklus I sebesar $29 \%$ menjadi $86 \%$ meningkat $57 \%$ dan kinerja guru SDN 150 Seluma di siklus I dari 43\% meningkat menjadi $86 \%$ atau ada peningkatan sebesar $43 \%$.
\end{abstract}

Kata kunci: supervisi kepala sekolah, motivasi guru, kinerja guru. 


\section{A. Pendahuluan}

Pendidik merupakan tenaga profesional yang bertugas merencanakan dan melaksanakan proses pembelajaran, menilai hasil pembelajaran, melakukan pembimbingan dan pelatihan, serta melakukan penelitian dan pengabdian kepada masyarakat, terutama bagi pendidik pada perguruan tinggi. Untuk dapat melaksanakan tugas dan tanggung jawab di atas, seorang guru dituntut memiliki beberapa kemampuan dan ketrampilan tertentu. Kemampuan dan ketrampilan tersebut sebagai bagian dari kompetensi profesionalisme guru. Kompetensi merupakan suatu kemampuan yang mutlak dimiliki oleh guru agar tugasnya sebagai pendidik dapat terlaksana dengan baik. Tugas guru erat kaitannya dengan peningkatan sumber daya manusia melalui sektor pendidikan, oleh karena itu perlu upaya-upaya untuk meningkatkan mutu guru untuk menjadi tenaga profesional. Peningkatan mutu pendidikan dapat berhasil tergantung pada banyak hal, terutama mutu gurunya $(\mathrm{H}$. AR. Tilaar, 2000:104).

Untuk menjadikan guru sebagai tenaga professional maka perlu diadakan pembinaan secara terus menerus dan berkesinambungan, serta menjadikan guru sebagai tenaga kerja perlu diperhatikan, dihargai dan diakui keprofesionalannya. Untuk membuat mereka menjadi professional tidak semata-mata hanya meningkatkan kompetensinya baik melalui pemberian penataran, pelatihan maupun memperoleh kesempatan untuk belajar lagi namun perlu juga memperhatikan guru dari segi yang lain seperti peningkatan disiplin, pemberian motivasi, pemberian bimbingan melalui supervisi, dan pemberian insentif yang layak dengan keprofesionalnya sehingga memungkinkan guru menjadi puas dalam bekerja sebagai pendidik.

Kinerja guru atau prestasi kerja adalah suatu hasil kerja yang dicapai seseorang dalam melaksanakan tugastugas yang dibebankan kepadanya yang didasarkan atas kecakapan, pengalaman, dan kesungguhan serta waktu (Malayau Hasibuan, 2002: 94). Kinerja guru akan baik jika guru telah melakukan unsur-unsur yang terdiri dari kesetiaan dan komitmen yang tinggi pada tugas mengajar, menguasai dan mengembangkan bahan pelajaran, kedisiplinan dalam mengajar dan tugas lainnya, kreativitas dalam pelaksanaan pengajaran, kerjasama dengan semua warga sekolah, kepemimpinan yang menjadi panutan siswa, kepribadian yang baik, jujur dan objektif dalam membimbing siswa, serta tanggung jawab terhadap tugasnya. Tugas kepala sekolah selaku pemimpin adalah melakukan penilaian terhadap kinerja guru. Penilaian ini penting untuk dilakukan mengingat fungsinya sebagai alat motivasi bagi pimpinan kepada guru maupun bagi guru itu sendiri.

Ada beberapa hal yang menyebabkan meningkatnya kinerja guru, namun penulis mencoba mengkaji masalah supervisi yang diberikan oleh kepala sekolah. Supervisi dalam hal ini adalah mengenai tanggapan guru terhadap pelaksanaan pembinaan dan bimbingan yang diberikan oleh kepala sekolah yang nantinya berdampak kepada kinerja guru yaitu kualitas pengajaran.

Selain kinerja, motivasi guru dalam melakukan tugas dan tanggung jawabnya juga merupakan hal penting bagi upaya meningkatkan proses pembelajaran yang akan dapat meningkatkan kualitas pendidikan yang ada. Motivasi kerja pada dasarnya merupakan sesuatu yang menimbulkan semangat atau dorongan dan kerja. Oleh sebab itu, motivasi kerja dalam psikologi sebagai pendorong semangat kerja (Pandji Anoraga, 2005:35). Guru menjadi seorang pendidik karena adanya motivasi untuk mendidik. Bila tidak punya motivasi maka ia tidak akan berhasil untuk mendidik/mengajar. Keberhasilan guru dalam mengajar karena dorongan/motivasi ini sebagai pertanda apa yang telah dilakukan oleh guru telah menyentuh kebutuhannya. Kegiatan mengajar yang dilakukan oleh guru yang diminatinya karena sesuai dengan kepentingannya sendiri. Guru yang termotivasi dalam bekerja maka akan menimbulkan kepuasan kerja, karena kebutuhan-kebutuhan guru yang terpenuhi mendorong guru meningkatkan kinerjanya.

Available online at : http://journal.pdmbengkulu.org/index.php/semar 
Permasalahan yang sering terjadi dalam proses pembelajaran yang dapat berdampak pada rendahnya kualitas pembelajaran adalah terletak pada masalah kinerja dan motivasi guru. Kinerja dan motivasi yang rendah pada guru akan dapat berpengaruh terhadap rendahnya kualitas pembelajaran yang ada di sekolah. Untuk itu perlu upaya yang dapat dilakukan dalam rangka mempertahankan sekaligus meningkatkan kinerja dan motivasi kerja guru di sekolah. Salah satu upaya yang dirasakan paling efektif dalam rangka meningkatkan kinerja dan motivasi kerja guru adalah mengoptimalkan peran kepala sekolah melalui supervisi.

"Supervisi pendidikan didefinisikan sebagai proses pemberian layanan bantuan profesional kepada guru untuk meningkatkan kemampuannya dalam melaksanakan tugas-tugas pengelolaan proses pembelajaran secara efektif dan efisien" (Ibrahim Bafadal, 2004: 46). Dengan adanya pelaksanaan supervisi oleh kepala sekolah diharapkan memberi dampak terhadap terbentuknya sikap professional guru. Sikap professional guru merupakan hal yang amat penting dalam memelihara dan meningkatkan profesionalitas guru, karena selalu berpengaruh pada perilaku dan aktivitas keseharian guru. Perilaku profesional akan lebih diwujudkan dalam diri guru apabila institusi tempat ia bekerja memberi perhatian lebih banyak pada pembinan, pembentukan, dan pengembangan sikap profesional (Made Pidarta, 2002:380).

Kegiatan supervisi kepala sekolah dan motivasi kerja guru akan berpengaruh secara psikologis terhadap kinerja guru, guru yang puas dengan pemberian supervisi kepala sekolah dan motivasi kerjanya tinggi maka ia akan bekerja dengan sukarela yang akhirnya dapat membuat kinerja guru meningkat. Tetapi jika guru kurang puas terhadap pelaksanaan supervisi kepala sekolah dan motivasi kerjanya rendah maka guru dalam bekerja kurang bergairah, hal ini mengakibatkan kinerja guru menurun.

Berdasarkan hasil wawancara yang dilakukan dengan beberapa Kepala Sekolah di Sekolah Dasar Negeri Seluma
Kecamatan Air Periukan Kabupaten Seluma ditemukan bahwa masih banyak kendala atau persoalan yang berkaitan dengan pelaksanaan supervisi kepala sekolah. Secara umum persoalan tersebut meliputi: kualitas supervisi dari kepala sekolah yang masih tergolong rendah. Padahal tujuan supervisi untuk membantu guru-guru melihat dengan jelas tujuan pendidikan dan berusaha mencapai tujuan pendidikan itu dengan membina serta mengembangkan metode-metode dan prosedur pengajaran yang lebih baik. Selain itu banyak guru kurang berhasil dalam mengajar dikarenakan mereka kurang termotivasi untuk mengajar sehingga berdampak terhadap menurunnya produktivitas/kinerja guru. Untuk itu diperlukan peran kepala sekolah untuk memotivasi para guru untuk meningkatkan kinerjanya.

Terkait dengan upaya peningkatan kinerja guru di Sekolah Dasar Negeri 150 Seluma Kecamatan Air Periukan Kabupaten Seluma, pihak Dinas Pendidikan Kabupaten Seluma selalu berupaya untuk meningkatkan kinerja para guru melalui perhatian terhadap kegiatankegiatan supervisi kepala sekolah, perhatian terhadap kesejahteraan guru dan upaya meningkatkan motivasi kerja guru di Sekolah Dasar di Kabupaten Seluma. Karena diketahui bahwa perhatian terhadap aspek-aspek tersebut sangat penting dalam upaya meningkatkan kinerja guru selama ini.

Supervisi kepala sekolah sebagai suatu aktivitas pembinaan yang direncanakan untuk membantu para guru dan pegawai sekolah diharapkan dapat membantu pencapaian tugas dan pekerjaan guru dan pegawai sekolah untuk dapat melaksanakan pekerjaannya secara efektif (M. Ngalim Purwanto, 2004:32). Selain itu melalui supervisi diharapkan dapat mengembangkan efektivitas kinerja guru dalam kaitannya dengan tugas-tugas utama pendidikan (Jones dalam Mulyasa, 2004: 155).

Bertitik tolak dari uraian di atas, maka penulis tertarik untuk mengadakan penelitian tindakan sekolah dengan judul "

Upaya Meningkatkan Motivasi Dan

Available online at : http://journal.pdmbengkulu.org/index.php/semar 
Kinerja Guru Melalui Supervisi Kepala Sekolah Pada Sekolah Dasar Negeri 150 Seluma Kecamatan Air Periukan Kabupaten Seluma Tahun Pelajaran 2016/2017." "

\section{B. Metode Penelitian}

1. Subyek Penelitian

Subjek dalam penelitian tindakan se kolah ini adalah guru -guru SD Negeri 150 Seluma Kecamatan Air Periukan Kabupaten Seluma yang berjumlah 7 orang, yang terdiri dari laki-laki 2 orang dan perempuan 5 orang

\section{Prosedur Penelitian}

Pelaksanaan penelitian tindakan sekolah ini dilakukan melalui tahapan sebagai berikut:

1. Penyusunan proposal penelitian,

2. Penyusunan instrument,

3. Pelaksanaan tindakan dalam rangka pengumpulan data,

4. Analisis data dan

5. Pembahasan hasil penelitian, serta

6. Penyusunan laporan PTS.

.Sumber data primer berasal dari hasil pengukuran variabel penelitian tindakan sekolah berikut skor kemampuan guru menyusun administrasi penilaian pembelajaran.Pelaksanaan penelitian tindakan sekolah ini dilakukan melalui dua siklus, di mana masing-masing siklus terdiri dari 4 tahap penting. Arikunto, Suhardjono, dan Supardi (2009: 75-80) mengemukakan bahwa dalam PTS terdiri dari 4 tahap, yaitu perencanaan, pelaksanaan tindakan, pengamatan, dan refleksi, sebagaimana gambar berikutMenurut Arikunto (2014: 58) PTK adalah penelitian yang dilakukan dengan tujuan memperbaiki mutu praktik pembelajaran di kelasnya. Penelitian ini dilaksanakan dalam dua siklus PTK dengan langkah-langkah yang sama yaitu: perencanaan, pelaksanaan, observasi, dan refleksi.

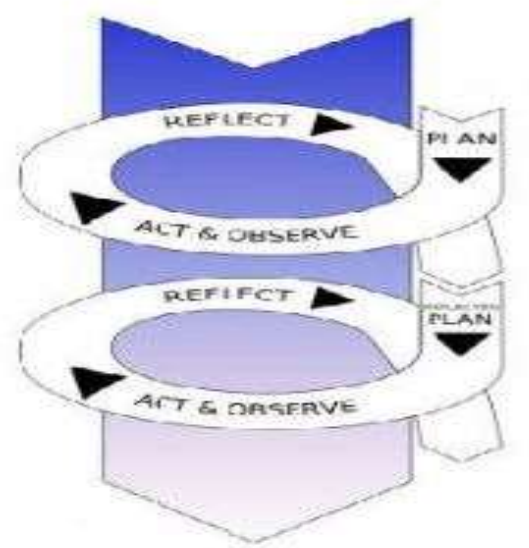

Gambar 1. Alur Langkah-Langkah PTK

Kegiatan penelitian ini dilakukan melalui beberapa tahap. Tahap-tahap dalam dalam PTS yang disampaikan oleh I.G.A.K. Wardani (2007: 2.4) sebagai

berikut: (1) merumuskan masalah, merencanakan tindakan dan persiapan (planning), (2) pengenalan tahap awal terhadap pengertian motivasi dan kinerja guru (3) penyusunan rencana tindakan (4) pelaksanaan yaitu implementasi tindakan (5) pengamatan, dan (6) refleksi.

1) Persiapan

Pada tahap persiapan peneliti memberitahu kepada guru Sekolah SD Negeri 150 Seluma bahwa peneliti akan melakukan kegiatan Penelitian Tindakan Sekolah (PTS). Penelitian Tindakan Sekolah ini dirancang untuk penyempurnaan atau peningkatan motivasi dan kinerja guru (Susilo, 2007: 16). Di dalam prosedur penelitian ini ditekankan pada mekanisme penelitian, pihak-pihak yang terkait secara aktif, alat atau instrumen yang digunakan adalah blanko pengamatan atau chek lis, kertas, dan jam.

2) Siklus I

Dalam penelitian ini rencana tindakan yang dilakukan berupa siklussiklus. Disetiap siklus memuat beberapa langkah untuk menyelesaikan permasalahan. George Boeree, (2008: 63-64) menjelaskan bahwa siklus-siklus dalam penelitian merupakan tahap awal 
untuk mencoba mengatasi permasalahan.

a. Perencanaan

Untuk melaksanakan tindakan dalam perencanaan pada siklus diperlukan rancangan yang dijadikan pedoman peneliti. Sementara yang dipersiapkan peneliti untuk dijadikan pedoman. Dalam penelitian ini perencanaan dilakukan dengan melakukan wawancara kepada kepala sekolah, terkait dengan pelaksanaan penelitian yaitu pelaksanaan supervisi kepela sekolah dalam rangka meningkatkan motivasi dan kinerja guru. Peneliti dan kepala sekolah melakukan kerja sama dalam rangka perencanaan kegiatan supervisi.

Perencanaan juga dilakukan dengan mempersiapkan antara lain yaitu :

1) Aspek penilaian motivasi dan kinerja.

2) Blangko penilaian motivasi dan kinerja

3) Pedoman observasi wawancara.

4) Menetapkan jadwal pelaksanaan supervisi.

b. Tindakan

Di dalam pelaksanaan supervisi kepala sekolah yang diterapkan dalam rangka meningkatkan motivasi dan kinerja guru di SD Negeri 150 Seluma Tahun 2016/2017 dilakukan baik secara perseorangan maupun secara kelompok. Supervisi perseorangan dilakukan dengan melakukan : 1) kunjungan kelas, 2) percakapan pribadi, 3) kunjungan antar kelas, 4) penilaian sendiri. Sedang teknik supervisi kelompok meliputi : 1) kepanitiaan, 2) kursus, 3) laboratorium kelompok, 4) bacaan terpimpin, 5) demonstrasi pembelajaran, 6) perjalanan staf, 7) diskusi panel, 8) perpustakaan profesional, 9) organisasi profesional, 10) bulletin supervisi, 11) sertifikasi guru, 12) tugas belajar, 13) pertemuan guru.

Supervisi dilakukan oleh kepala sekolah setiap saat pada kelas-kelas terkait motivasi dan kinerja guru dalam proses pembelajaran. Pelaksanaan supervisi juga dilakukan dengan melakukan diskusi dan memberikan arahan kepada guru terkait dengan permasalahan yang dijumpai pada saat supervisi. Seperti ada kelas yang terlihat sangat ramai dan gaduh. Pada saat itu pula kepala sekolah memberikan pengarahan kepada guru untuk mengatasinya. Selain itu juga apabila terdapat kelas yang ditinggalkan oleh gurunya kepala sekolah juga harus mengarahkan kepada guru piket untuk segera mengatasinya.

Dari hasil pelaksanaan supervise kepala sekolah tersebut diharapkan kepala sekolah akan dapat melakukan penilaian atau evaluasi terhadap motivasi dan kinerja guru yang sesungguhnya. Supervisi dilakukan tanpa adanya pemberitahuan terlebih dahulu. Dalam setiap pelaksanaan supervisi kepala sekolah memberikan penilaian terhadap aspek motivasi dan kinerja sesuai dengan yang telah direncanakan untuk mengetahui penilaian motivasi dan kinerja setiap guru dalam proses pembelajaran.

c. Observasi

Dalam penelitian ini observasi dilakukan mulai sebelum pelaksanaan tindakan yang ditujukan untuk mengetahui kondisi awal, selama pelaksanaan tindakan dan setelah pelaksanaan supervise terkait dengan penilaian terhadap motivasi dan kinerja guru dalam proses pembelajaran.

Dengan demikian obeservasi dalam penelitian ini dilaksanakan selama proses pembelajaran peneliti mengadakan analisis kelebihan dan kekurangan dari tindakan tersebut. Kekurangan yang ditemukan pada siklus I akan diperbaiki pada siklus berikutnya. Observasi yang dilakukan terhadap guru selama satu minggu pada siklus satu, selalu dievaluasi dan dianalisa terkait dengan motivasi guru dan kinerja guru. Supervisi kepala sekolah dilaksanakan selama satu minggu terhadap semua kegiatan guru yang ada di sekolah, baik kegiatan pembelajaran di kelas maupun kegiatan di luar pembelajaran di dalam kelas.

d. Evaluasi dan Refleksi

Evaluasi atau penilaian dilakukan untuk menentukan apakah terdapat peningkatan motivasi dan kinerja guru setelah dilakukan supervisi kepala sekolah. Apabila dalam pelaksanaannya masih terdapat kekurangan dan target

Available online at : http://journal.pdmbengkulu.org/index.php/semar 
pencapaian motivasi dan kinerja guru belum tercapai, maka perlu adanya langkah perbaikan terhadap pelaksanaan supervisi untuk siklus berikutnya agar dalam penerapannya dapat meningkatkan motivasi dan kinerja guru.

Dari hasil penilaian terhadap pelaksanaan tindakan pada siklus I, maka perlu dilakukan refleksi apakah pelaksanaan tindakan pada siklus I tersebut mampu mencapai target peningkatan motivasi dan kinerja yang telah ditetapkan yaitu $75 \%$ guru mempunyai penilaian terhadap motivasi dan kinerja yag baik. Apabila dalam penilaian masih di bawah target yang ditetapkan, maka perlu dilakukan perbaikan atas pelaksanaan tindakan terhadap siklus I pada siklus berikutnya.

3) Siklus II

\section{a. Perencanaan}

Untuk melaksanakan tindakan dalam perencanaan pada siklus II tentu saja didasarkan pada hasil refleksi pada siklus I. Dari hasil observasi atas kekurangan yang ada pada siklus I akan diperbaiki pada siklus II. Untuk itu dalam perencanaan siklus II dalam penelitian ini pada dasarnya hampir sama dengan perencanaan yang ada pada siklus I dan memberikan penambahan terhadap kekeurangan yang ada pada pelaksanaan siklus I. Untuk perencanaan siklus II secara teknis sama dengan perencanaan siklus I antara lain yaitu :

1) Mempersiapkan aspek penilaian motivasi dan kinerja.

2) Blangko penilaian motivasi dan kinerja

3) Pedoman observasi wawancara.

4) Menetapkan jadwal pelaksanaan supervisi

5) Memilih teknik supervisi yang efektif.

b. Tindakan

Di dalam pelaksanaan supervisi kepala sekolah yang diterapkan dalam rangka meningkatkan motivasi dan kinerja guru SD Negeri 150 Seluma Kecamatan Air Periukan Kabupaten Seluma Tahun Pelajaran 2016/2017. Pada siklus II dilakukan baik secara perseorangan maupun secara kelompok. Supervisi perseorangan dilakukan dengan melakukan : 1) kunjungan kelas, 2) percakapan pribadi, 3) kunjungan antar kelas, 4) penilaian sendiri. Sedang teknik supervisi kelompok meliputi : 1) kepanitiaan, 2) kursus, 3) laboratorium kelompok, 4) bacaan terpimpin, 5) demonstrasi pembelajaran, 6) perjalanan staf, 7) diskusi panel, 8) perpustakaan profesional, 9) organisasi profesional, 10) bulletin supervisi, 11) sertifikasi guru, 12) tugas belajar, 13) pertemuan guru.

Supervisi dilakukan oleh kepala sekolah setiap saat pada kelas-kelas terkait motivasi dan kinerja guru dalam proses pembelajaran. Pelaksanaan supervisi juga dilakukan dengan melakukan diskusi dan memberikan arahan kepada guru terkait dengan permasalahan yang dijumpai pada saat supervisi. Seperti ada kelas yang terlihat sangat ramai dan gaduh. Pada saat itu pula kepala sekolah memberikan pengarahan kepada guru untuk mengatasinya. Selain itu juga apabila terdapat kelas yang ditinggalkan oleh gurunya kepala sekolah juga harus mengarahkan kepada guru piket untuk segera mengatasinya.

Dari hasil pelaksanaan supervisi kepala sekolah tersebut diharapkan kepala sekolah akan dapat melakukan penilaian atau evaluasi terhadap motivasi dan kinerja guru yang sesungguhnya. Supervisi dilakukan tanpa adanya pemberitahuan terlebih dahulu. Dalam setiap pelaksanaan supervisi kepala sekolah memberikan penilaian terhadap aspek motivasi dan kinerja sesuai dengan yang telah direncanakan untuk mengetahui penilaian motivasi dan kinerja setiap guru dalam proses pembelajaran.

\section{c. Observasi}

Dalam penelitian ini observasi dilakukan mulai sebelum pelaksanaan tindakan yang ditujukan untuk mengetahui kondisi awal, selama pelaksanaan tindakan dan setelah pelaksanaan supervise terkait dengan penilaian terhadap motivasi dan kinerja guru dalam proses pembelajaran.

Dengan demikian obeservasi dalam penelitian ini dilaksanakan selama proses 
pembelajaran peneliti mengadakan analisis kelebihan dan kekurangan dari tindakan tersebut. Kekurangan yang ditemukan pada siklus II akan diperbaiki pada siklus berikutnya dan apabila dengan pelaksanaan supervisi tersebut telah mampu mencapai target motivasi dan kinerja yang ditetapkan yaitu $75 \%$ guru mempunyai motivasi dan kinerja yang baik, maka supervisi dalam siklus II akan tetap dipertahankan untuk dapat mempertahankan motivasi dan kinerja guru.

Observasi yang dilakukan terhadap guru selama satu minggu pada siklus satu, selalu dievaluasi dan dianalisa terkait dengan motivasi guru dan kinerja guru. Supervisi kepala sekolah dilaksanakan selama satu minggu terhadap semua kegiatan guru yang ada di sekolah, baik kegiatan pembelajaran di kelas maupun kegiatan di luar pembelajaran di dalam kelas.

\section{d. Evaluasi dan Refleksi}

Evaluasi atau penilaian dilakukan untuk menentukan apakah terdapat peningkatan motivasi dan kinerja guru setelah dilakukan supervisi kepala sekolah. Apabila dalam pelaksanaannya masih terdapat kekurangan dan target pencapaian motivasi dan kinerja guru belum tercapai, maka perlu adanya langkah perbaikan terhadap pelaksanaan supervisi untuk siklus berikutnya agar dalam penerapannya dapat meningkatkan motivasi dan kinerja guru.

Dalam penilaian pada siklus ini dilakukan dengan memberikan penilaian secara langsung oleh kepala sekolah terhadap aspek penilaian motivasi dan kinerja guru selama pelaksanaan supervisi. Sehingga kepala sekolah melakukan penilaian setiap aspek motivasi dan kinerja guru yang ada pada saat pelaksanaan supervisi berjalan

\section{Teknik Analisis Data}

Sebagai tolok ukur keberhasilan penelitian tindakan sekolah, bahwa pelaksanaan supervisi kepala sekolah terhadap motivasi dan kinerja guru dinyatakan berhasil jika:
1) Motivasi guru : dinyatakan tinggi jika mencapai nilai antara 17 sampai dengan 24 dari instrument penilaian motivasi kerja guru.

\section{Hasil dan Pembahasan penelitian 1. Hasil Penelitian}

Berdasarkan penilaian kinerja guru pada kondisi awal (pra siklus) dapat diketahui bahwa guru yang mempunyai penilaian kinerja yang cukup baik ada 6 orang atau mencapai $75 \%$ dari total guru yang diamati. Sedangkan guru yang mempunyai penilaian kinerja yang kurang baik terdapat 2 guru atau 25\% dari total guru yang diamati dalam penelitian ini. Selain itu dapat dketahui bahwa rata-rata penilaian kinerja guru pada kondisi awal (pra siklus) menunjukkan nilai 5,98 atau masuk dalam kategori kurang baik. Dengan demikian dapat diketahui bahwa kinerja guru yang ada di SD Negeri 150 Seluma Kecamatan Air Periukan Kabupaten Seluma Tahun Pelajaran 2016/2017 sebelum adanya tindakan supervisi kepala sekolah masih sangat rendah.

Berdasarkan hasil penilaian terhadap kondisi awal terkait dengan penilaian kinerja guru yang masih rendah, maka perlu mendapatkan tindakan untuk dapat meningkatkan kinerja guru. Salah satu upaya yang diterapkan SD Negeri 150 Seluma Kecamatan Air Periukan Kabupaten Seluma Tahun Pelajaran 2016/2017 yaitu dengan melaksanakan supervisi kepala sekolah.

1) Siklus I

Dalam siklus I dilaksanakan sebagai bentuk upaya untuk dapat mengatasi masalah rendahnya motivasi dan kinerja guru yang ada di SD Negeri 150 Seluma Kecamatan Air Periukan Kabupaten Seluma Tahun Pelajaran 2016/2017 . Dalam pelaksanaan supervisi kepala sekolah pada siklus I dilakukan dengan menggunakan teknik supervisi perorangan seperti : 1) kunjungan kelas, 2) percakapan pribadi, 3) kunjungan antar kelas, 4) penilaian sendiri. Sedang teknik supervisi kelompok meliputi : 1) kepanitiaan, 2) kursus, 3) laboratorium kelompok, 4) bacaan terpimpin, 5) demonstrasi pembelajaran, 6) perjalanan 
staf, 7) diskusi panel, 8) perpustakaan profesional, 9) organisasi profesional, 10) bulletin supervisi, 11) sertifikasi guru, 12) tugas belajar, 13) pertemuan guru. (Sardiman, 2005:83).

Supervisi dilakukan oleh kepala sekolah terkait motivasi dan kinerja guru dalam proses pembelajaran. Pelaksanaan supervisi juga dilakukan dengan melakukan diskusi dan memberikan arahan kepada guru terkait dengan permasalahan yang dijumpai pada saat supervisi. Seperti ada kelas yang terlihat sangat ramai dan gaduh. Pada saat itu pula kepala sekolah memberikan pengarahan kepada guru untuk mengatasinya. Selain itu juga apabila terdapat kelas yang ditinggalkan oleh gurunya kepala sekolah juga harus mengarahkan kepada guru piket untuk segera mengatasinya.
Dari hasil pelaksanaan supervisi kepala sekolah tersebut diharapkan kepala sekolah dapat melakukan penilaian atau evaluasi terhadap motivasi dan kinerja guru yang sesungguhnya, salah satunya berupa sidak atau inspeksi mendadak. Inspeksi mendadak dilakukan tanpa adanya pemberitahuan terlebih dahulu. Dalam setiap pelaksanaan supervisi kepala sekolah memberikan penilaian terhadap aspek motivasi dan kinerja sesuai dengan yang telah direncanakan untuk mengetahui penilaian motivasi dan kinerja setiap guru dalam proses pembelajaran.

Dengan adanya pelaksanaan supervisi pada siklus I dalam penelitian ini, dapat diketahui hasil observasi kepala sekolah terhadap hasil penilaian motivasi dan kinerja guru pada siklus I.

Adapun hasil penilaian motivasi guru pada siklus I secara rinci dapat dilihat pada tabel di bawah ini.

Tabel 1. Penilaian Motivasi Guru pada Siklus I

\begin{tabular}{|c|c|c|c|c|c|c|}
\hline \multirow[b]{2}{*}{ No. } & \multirow[b]{2}{*}{ Nama/NIP } & \multirow[b]{2}{*}{ Gol } & \multicolumn{3}{|c|}{ Kategori } & \multirow[b]{2}{*}{ Ket } \\
\hline & & & $\begin{array}{l}\text { Tinggi } \\
(3)\end{array}$ & $\begin{array}{l}\text { Sedang } \\
(2)\end{array}$ & $\begin{array}{l}\text { Rendah } \\
\text { (1) }\end{array}$ & \\
\hline 1 & $\begin{array}{l}\text { Herman Sawiran, S.Pd.SD } \\
196908071991041004\end{array}$ & IV.a & $\sqrt{ }$ & & & \\
\hline 2 & $\begin{array}{l}\text { Tasaria, S.Pd.SD } \\
197005072007012040\end{array}$ & IV.a & $\sqrt{ }$ & & & \\
\hline 3 & $\begin{array}{l}\text { Betty Odor,S. S.Pd.SD } \\
196603242006042002\end{array}$ & III.b & & $\sqrt{ }$ & & \\
\hline 4 & $\begin{array}{l}\text { Aris Juyardi, S.Pd.SD } \\
198512222010011009\end{array}$ & III.a & & $\sqrt{ }$ & & \\
\hline 5 & Rosita, S.Pd.SD & - & & $\sqrt{ }$ & & \\
\hline 6 & Delvit Dahlia, S.Pd & - & & $\sqrt{ }$ & & \\
\hline 7 & Wati & - & & $\sqrt{ }$ & & \\
\hline \multicolumn{3}{|c|}{ Jumlah } & 2 & 5 & & \\
\hline \multicolumn{3}{|c|}{ Rata - rata } & $29 \%$ & $71 \%$ & & \\
\hline \multicolumn{3}{|c|}{$\begin{array}{l}\text { Berdasarkan analisis motivasi kerja } \\
\text { tertera pada tabel } 4.2 \text { di atas guru } \\
\text { termasuk kategori tinggi ada } 2 \text { orang } \\
29 \% \text { dan guru yang masuk kategori }\end{array}$} & $\begin{array}{l}\text { dang } s \\
\text { dangkar } \\
\text { ihat pad } \\
\text { rikut: }\end{array}$ & $\begin{array}{l}\text { banyak } 5 \\
\text { penilaian } \\
\text { tabel di }\end{array}$ & $\begin{array}{l}\text { orang } \\
\text { kinerja } \\
\text { bawah i }\end{array}$ & \\
\hline
\end{tabular}


Tabel 2 Penilaian Kinerja Guru Siklus I

\begin{tabular}{|c|c|c|c|c|c|c|}
\hline \multirow[b]{2}{*}{ No. } & \multirow[b]{2}{*}{ Nama/NIP } & \multirow[b]{2}{*}{ Gol } & \multicolumn{3}{|c|}{ Kategori } & \multirow[b]{2}{*}{ Ket } \\
\hline & & & $\begin{array}{c}\text { Baik } \\
(3)\end{array}$ & $\begin{array}{c}\text { Cukup } \\
(2)\end{array}$ & $\begin{array}{c}\text { Kurang } \\
(1)\end{array}$ & \\
\hline 1 & $\begin{array}{l}\text { Herman Sawiran, S.Pd.SD } \\
196908071991041004\end{array}$ & IV.a & $\sqrt{ }$ & & & \\
\hline 2 & $\begin{array}{l}\text { Tasaria, S.Pd.SD } \\
19700507197005072\end{array}$ & IV.a & $\sqrt{ }$ & & & \\
\hline 3 & $\begin{array}{c}\text { Betty Odor,S. S.Pd.SD } \\
196603242006042002 \\
\end{array}$ & III.b & $\sqrt{ }$ & & & \\
\hline 4 & $\begin{array}{l}\text { Aris Juyardi, S.Pd.SD } \\
198512222010011009\end{array}$ & III.a & & $\sqrt{ }$ & & \\
\hline 5 & Rosita, S.Pd.SD & - & & $\sqrt{ }$ & & \\
\hline 6 & Delvit Dahlia, S.Pd & - & & $\sqrt{ }$ & & \\
\hline 7 & Wati & - & & $\sqrt{ }$ & & \\
\hline \multicolumn{3}{|c|}{ Jumlah } & 3 & 4 & & \\
\hline \multicolumn{3}{|c|}{ Rata - rata } & $43 \%$ & $57 \%$ & & \\
\hline
\end{tabular}

Sumber : Data primer yang diolah.

Berdasarkan penilaian motivasi pada siklus I dapat diketahui bahwa guru yang mempunyai penilaian motivasi tinggi ada 2 orang atau mencapai $29 \%$ dari total guru yang diamati. Sedangkan guru yang mempunyai penilaian motivasi sedang terdapat 5 guru atau $71 \%$ dari total guru yang diamati dalam penelitian ini.

Dengan demikian dapat diketahui bahwa motivasi guru yang ada di SD Negeri 150 Seluma Kecamatan Air Periukan Kabupaten Seluma Tahun Pelajaran 2016/2017 pelaksanaan supervisi yang dilakukan oleh kepala sekolah dilakukan dengan supervisi perorangan maupun kelompok belum dapat meningkatkan motivasi kerja guru. Terbukti peningkatan motivasi guru dari penilaian rata-rata motivasi guru semula pada kondisi pra siklus menunjukkan ratarata penilaian yang rendah meningkat menjadi sedang.

Meskipun demikian peningkatan motivasi guru setelah dilaksanakn supervisi kepala sekolah pada siklus I belum mampu mencapai target peningkatan motivasi kerja guru sesuai yang ditetapkan yaitu $75 \%$ guru mempunyai penilaian motivasi yang tinggi. Untuk itu dalam pelaksanaan siklus I ini perlu dilakukan evaluasi dan refleksi.

Sementara itu dengan adanya pelaksanaan supervisi kepala sekolah SD Negeri 150 Seluma pada tahun pelajaran 2016/2017 yang telah dilakukan pada siklus I belum juga menunjukkan peningkatan kinerja guru yang masuk kategori baik mencapai $75 \%$.

Berdasarkan penilaian kinerja guru pada siklus I dapat diketahui bahwa guru yang mempunyai penilaian kinerja yang baik ada 3 orang atau mencapai $43 \%$ dari total guru yang diamati. Sedangkan guru yang mempunyai penilaian kinerja yang cukup ada 4 guru atau 57\% dari total guru yang diamati dalam penelitian ini. Dengan demikian dapat diketahui bahwa kinerja guru yang ada di SD Negeri 150 Seluma Kecamatan Air Periukan Kabupaten Seluma tahun pelajaran 2016/2017 belum mengalami peningkatan secara signifikan setelah dilaksanakannya supervisi kepala sekolah.

Berdasarkan hasil evaluasi dari pelaksanaan siklus I pada penelitian ini dapat diketahui bahwa terdapat peningkatan motivasi dan kinerja guru

Available online at : http://journal.pdmbengkulu.org/index.php/semar 
yang ada di SD Negeri 150 Seluma dari keadaan pada prasiklus. Dimana semula motivasi guru rata-rata termasuk dalam penilaian rendah meningkat menjadi sedang dengan penilaian rata-rata semula $57 \%$ meningkat menjadi kategori sedang sebesar $71 \%$. Sedangkan untuk kinerja guru yang semula rata-rata penilaian kurang meningkat menjadi rata-rata mempunyai penilaian cukup dengan skor rata-rata meningkat menjadi $57 \%$. Meskipun demikian peningkatan motivasi dan kinerja guru pada siklus ini belum mampu mencapai target yang telah ditetapkan yaitu $75 \%$ yang baik.

Dari hasil pelaksanaan supervisi kepala sekolah pada siklus I masih terdapat banyak kekurangan yang masih perlu diperbaiki agar mampu menghasilkan aktivitas supervisi kepala sekolah yang efektif. Dimana dalam pelaksanaan supervisi pada siklus I belum dilaksanakan secara matang mengingat perencanaan yang dilakukan masih terbatas pada perencanaan yang sederhana. Perencanaan kegiatan supervisi yang dilaksanakan pada siklus I belum dilakukan secara trstruktur dengan baik. Selain itu kurangnya koordinasi antara kepala sekolah dengan guru dalam pelaksanaan supervisi. Kepala sekolah kurang dapat memanfaatkan fasilitas dan sumber daya yang ada di sekolah guna mendukung kegiatan supervisi.

Sebagai bentuk refleksi dalam penelitian ini, masih dibutuhkan perencanaan yang lebih matang untuk menghasilkan supervisi kepala sekolah yang lebih efektif. Selain itu diperlukan adanya koordinasi antara kepala sekolah dengan guru guna meningkatkan efektifitas pelaksanaan supervisi ini. Untuk itu dalam pelaksanaan supervisi ini perlu dilakukan perbaikan pada siklus berikutnya.

2) Siklus II

Dalam siklus II dilaksanakan sebagai bentuk refleksi dari pelaksanaan supervisi kepala sekolah yang telah dilakukan pada siklus I dalam rangka meningkatkan motivasi dan kinerja guru di SD Negeri 150 Seluma tahun pelajaran 2016/2017. Dalam pelaksanaan supervisi kepala sekolah pada siklus II pada dasarnya sama dengan apa yang telah dilaksanakan pada siklus I dengan menggunakan teknik supervisi perorangan seperti : 1) kunjungan kelas, 2) percakapan pribadi, 3) kunjungan antar kelas, 4) penilaian sendiri.

Meskipun demikian dalam pelaksanaan supervisi pada siklus II ini dilakukan perencanaan yang lebih matang dengan melibatkan guru dan melakukan koordinasi antara kepala sekolah dengan guru dalam rangka upaya meningkatkan motivasi dan kinerja guru. Kepala sekolah lebih serius dalam melakukan kegiatan supervisi. Kepala sekolah secara rutin melakukan kunjungan ke masing-masing kelas, melakukan diskusi dengan guru kelas, menanyakan tentang keadaan dan perkembangan kelas yang diasuh masingmasing guru, kepala sekolah juga melibatkan guru-guru dalam aktivitas diluar kelas, dan memberikan kesempatan kepada guru untuk berupaya mengembangkan kreativitasnya dalam mengajar serta memberikan arahan kepada setiap guru untuk memanfaatkan segala fasilitas dan sumber daya yang ada di sekolah guna mendukung proses belajar yang lebih baik.

Dalam pelaksanaan supervisi pada siklus II ini, kepala sekolah juga menanyakan kepada anak didik tentang kondisi belajar yang ada di kelas masingmasing, selain itu juga selalu berupaya untuk memberikan dukungan baik fisik maupun mental terhadap semua guru maupun peserta didik dalam meningkatkan prestasi belajar peserta didik. Kepala sekolah selalu memberikan kesempatan kepada para guru untuk menyampaikan aspirasi atau pendapatnya dalam upaya mengembangkan proses belajar di sekolah.

Dengan adanya kegiatan supervisi pada siklus II ini, maka dapat diketahui hasil penilaian terhadap motivasi dan kinerja guru di SD Negeri 150 Seluma. Adapun hasil penilaian motivasi guru pada siklus II dalam penelitian ini secara rinci dapat dilihat pada tabel di bawah ini. 
Tabel 3.Penilaian Motivasi Guru pada Siklus II

\begin{tabular}{|c|c|c|c|c|c|c|}
\hline \multirow[b]{2}{*}{ No. } & \multirow[b]{2}{*}{ Nama/NIP } & \multirow[b]{2}{*}{ Gol } & \multicolumn{3}{|c|}{ Kategori } & \multirow[b]{2}{*}{ Ket } \\
\hline & & & $\begin{array}{l}\text { Tinggi } \\
(3)\end{array}$ & $\begin{array}{l}\text { Sedang } \\
(2)\end{array}$ & $\begin{array}{c}\text { Rendah } \\
\text { (1) }\end{array}$ & \\
\hline 1 & $\begin{array}{l}\text { Herman Sawiran, } \\
\text { S.Pd.SD } 19690807 \\
1991041004\end{array}$ & IV.a & $\sqrt{ }$ & & & \\
\hline 2 & $\begin{array}{l}\text { Tasaria, S.Pd.SD } \\
1970050719700507 \\
2007012040\end{array}$ & IV.a & $\sqrt{ }$ & & & \\
\hline 3 & $\begin{array}{l}\text { Betty Odor,S. S.Pd.SD } \\
196603242006042002\end{array}$ & III.b & $\sqrt{ }$ & & & \\
\hline 4 & $\begin{array}{l}\text { Aris Juyardi, S.Pd.SD } \\
198512222010011009\end{array}$ & III.a & $\sqrt{ }$ & & & \\
\hline 5 & Rosita, S.Pd.SD & - & $\sqrt{ }$ & & & \\
\hline 6 & Delvit Dahlia, S.Pd & - & $\sqrt{ }$ & & & \\
\hline 7 & Wati & - & & $\sqrt{ }$ & & \\
\hline \multicolumn{3}{|c|}{ Jumlah } & 6 & 1 & & \\
\hline \multicolumn{3}{|c|}{ Rata - rata } & $86 \%$ & $14 \%$ & & \\
\hline
\end{tabular}

Sumber : Data primer yang diolah. Berdasarkan penilaian motivasi pada siklus II dapat diketahui bahwa guru yang mempunyai penilaian motivasi yang tinggi ada 6 orang atau $86 \%$ dari total guru yang diamati. Sedangkan guru yang mempunyai penilaian motivasi yang sedang terdapat 1 guru atau $14 \%$ dari total guru yang diamati dalam penelitian ini. Dengan demikian dapat diketahui bahwa motivasi guru SD Negeri 150 Seluma tahun pelajaran 2016/2017 setelah pelaksanaan supervisi kepala sekolah yang dilakukan secara terstruktur terbukti dapat meningkatkan motivasi guru SD Negeri 150 Seluma.

Dengan hasil penelitian ini terbukti bahwa pelaksanaan supervisi kepala sekolah dapat meningkatkan motivasi guru, kondisi ini dapat dilihat dari penilaian rata-rata motivasi guru pada kondisi siklus
I menunjukkan rata-rata penilaian yang sedang meningkat menjadi tinggi.

Dari hasil pelaksanaan supervisi kepala sekolah yang telah dilakukan pada siklus II menunjukkan bahwa terdapat 6 guru atau $86 \%$ dari seluruh guru yang diamati dalam penelitian yang sudah mampu menunjukkan motivasi yang tinggi. Dengan demikian dapat diketahu bahwa target pencapaian dalam pelaksanaan tindakan pada penelitian ini sudah tercapai. Dimana lebih dari $75 \%$ guru telah mampu mendapatkan penilaian motivasi yang tinggi.

Sementara itu dengan adanya pelaksanaan supervisi kepala sekolah yang telah dilakukan pada siklus II juga menunjukkan peningkatan kinerja guru yang ada di SD Negeri 150 Seluma tahun pelajaran 2016/2017. Adapun peningkatan kinerja guru dengan adanya pelaksanaan supervisi kepala sekolah dalam siklus II

Available online at : http://journal.pdmbengkulu.org/index.php/semar 
secara rinci dapat dilihat pada tabel di bawah ini.

Tabel 4.5. Penilaian Kinerja Guru pada Siklus II

\begin{tabular}{|c|c|c|c|c|c|c|}
\hline \multirow[b]{2}{*}{ No. } & \multirow[b]{2}{*}{ Nama/NIP } & \multirow[b]{2}{*}{ Gol } & \multicolumn{3}{|c|}{ Kategori } & \multirow[b]{2}{*}{ Ket } \\
\hline & & & $\begin{array}{c}\text { Baik } \\
(3)\end{array}$ & $\begin{array}{c}\text { Cukup } \\
\text { (2) }\end{array}$ & $\begin{array}{c}\text { Kurang } \\
\text { (1) }\end{array}$ & \\
\hline 1 & $\begin{array}{l}\text { Herman Sawiran, S.Pd.SD } \\
196908071991041004\end{array}$ & IV.a & $\sqrt{ }$ & & & \\
\hline 2 & $\begin{array}{l}\text { Tasaria, S.Pd.SD } \\
197005072007012040\end{array}$ & IV.a & $\sqrt{ }$ & & & \\
\hline 3 & $\begin{array}{l}\text { Betty Odor,S. S.Pd.SD } \\
196603242006042002\end{array}$ & III.b & $\sqrt{ }$ & & & \\
\hline 4 & $\begin{array}{l}\text { Aris Juyardi, S.Pd.SD } \\
198512222010011009\end{array}$ & III.a & $\sqrt{ }$ & & & \\
\hline 5 & Rosita, S.Pd.SD & - & $\sqrt{ }$ & & & \\
\hline 6 & Delvit Dahlia, S.Pd & - & $\sqrt{ }$ & & & \\
\hline 7 & Wati & - & & $\sqrt{ }$ & & \\
\hline \multicolumn{3}{|c|}{ Jumlah } & 6 & 1 & & \\
\hline \multicolumn{3}{|c|}{ Rata - rata } & $86 \%$ & $14 \%$ & & \\
\hline
\end{tabular}

Sumber : Data primer yang diolah.

Berdasarkan penilaian kinerja guru pada siklus II dapat diketahui bahwa guru yang mempunyai penilaian kinerja yang baik ada 6 orang atau mencapai $86 \%$ dari total guru yang diamati. Sedangkan guru yang mempunyai penilaian kinerja yang cukup terdapat 1 guru atau 14\% dari total guru yang diamati dalam penelitian ini. Dengan demikian dapat diketahui bahwa kinerja guru yang ada di SD Negeri 150 Seluma tahun pelajaran 2016/2017 mengalami peningkatan setelah dilaksanakannya supervisi kepala sekolah yang dilakukan lebih terstruktur pada siklus II ini. Peningkatan penilaian kinerja guru dapat dilihat dari yang semula mempunyai rata-rata penilaian $43 \%$ meningkat menjadi $86 \%$.

Berdasarkan hasil evaluasi dari pelaksanaan siklus II pada penelitian ini dapat diketahui bahwa terdapat peningkatan motivasi dan kinerja guru yang ada di SD Negeri 150 Seluma. Dimana motivasi guru rata-rata pada siklus II ini telah menunjukkan penilaian yang tinggi. Sementara itu kinerja guru dalam siklus II ini juga menunjukkan peningkatan yang cukup signifikan. Hasil penilaian kinerja guru pada siklus II ini menunjukkan bahwa penilaian kinerja guru menunjukkan penilaian yang baik.

Dengan demikian dapat dipastikan bahwa pelaksanaan supervisi kepala sekOlah yang dilaksanakan secara 
terencana dan terstruktur akan dapat menghasilkan proses supervisi yang lebih baik. Hal ini terbukti bahwa dengan perencanaan yang lebih matang dan pelaksanaan yang lebih terintergrasi antara guru dan pihak-pihak lain yang terkait dengan segala aktivitas yang ada di sekolah baik di dalam kelas maupun diluar kelas akan dapat menghasilkan proses supervisi yang baik. Dengan proses supervisi yang baik mampu meningkatkan motivasi dan kinerja guru dan terbukti mampu meningkatkan motivasi guru dan kinerja guru yang baik. Pelaksanaan supervisi ini juga telah mencapai target pencapaian tindakan mencapai $86 \%$ melebihi target keberhasilan tindakan yaitu $\geq 75 \%$.

\section{Pembahasan}

Berdasarkan hasil penelitian tindakan yang terkait dengan upaya meningkatkan motivasi dan kinerja guru melalui pelaksanaan supervisi kepala sekolah SD Negeri 150 Seluma tahun pelajaran 2016/2017 ini maka dapat ditarik pembahasan bahwa pelaksanaan supervisi kepala sekolah yang ada selama ini belum dapat dilaksanakan secara efektif. Namun setelah pelaksanaan tindakan ini membuktikan bahwa pelaksanaan supervisi kepala sekolah mampu memberikan kontribusi yang positif terhadap peningkatan motivasi dan kinerja guru SD Negeri 150 Seluma tahun pelajaran 2016/2017.

Dari hasil penelitian ini terbukti bahwa pelaksanaan supervisi kepala sekolah yang dilakukan secara efektif akan dapat meningkatkan movitasi dan kinerja guru yang ada SD Negeri 150 Seluma. Hal ini terbukti dari adanya peningkatan penilaian motivasi dan kinerja guru pada siklus I, dan siklusll dari $29 \%$ meningkat menjadi $86 \%$.

Adapun peningkatan motivasi kerja guru SD Negeri 150 Seluma tahun pelajaran 2016/2017 dengan adanya supervisi kepala sekolah secara rinci dapat dilihat pada grafik di bawah ini:

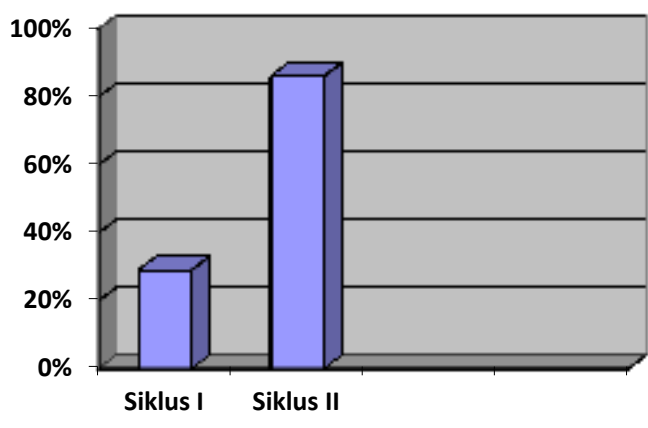

Gambar 2. Peningkatan Penilaian Motivasi Guru

Pelaksanaan supervisi kepala sekolah dalam penelitian ini juga terbukti mampu meningkatkan kinerja guru SD Negeri 150 Seluma tahun pelajaran 2016/2017. Hal ini dapat terlihat dari adanya peningkatan yang signifikan terhadap kinerja guru dengan adanya pelaksanaan supervisi kepala sekolah SD Negeri 150 Seluma. Adapun peningkatan kinerja guru dengan adanya pelaksanaan supervisi kepala sekolah dalam penelitian ini semula $43 \%$ menjadi $86 \%$ dan secara rinci dapat dilihat pada grafik di bawah ini.

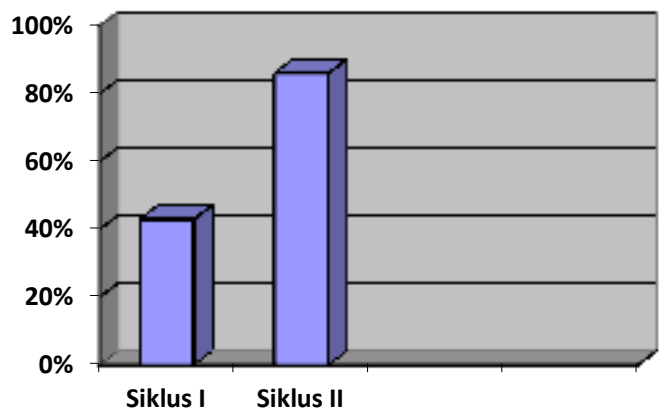

\section{Gambar 3 Peningkatan Penilaian Kinerja Guru}

Berdasarkan hasil penelitian ini maka dapat diketahui bahwa pelaksanaan supervisi kepala sekolah terbukti dapat meningkatkan motivasi dan kinerja guru. Untuk itu pelaksanaan supervisi kepala sekolah dapat dilaksanakan dalam rangka mempertahankan sekaligus meningkatan motivasi dan kinerja guru. Dalam pelaksanaan supervisi kepala sekolah 
tentu saja perlu dilakukan perencanaan yang terstruktur dan dilaksanakan secara sistematis agar mampu menghasilkan proses supervisi yangbaik. Dengan adanya pelaksanaan supervisi yang baik diharapkan akan dapat meningkatkan motivasi dan kinerja guru guna mendukung pencapaian tujuan pembelajaran yang lebih baik.

\section{Kesimpulan Dan Saran}

\section{Kesimpulan}

Berdasarkan hasil penelitian dan pembahasan dalam penelitian ini Pelaksanaan supervisi kepala sekolah ternyata dapat meningkatkan motivasi dan kinerja guru di SD Negeri 150 Seluma Kecamatan Air Periukan Kabupaten Seluma Tahun Pelajaran 2016/2017 terbukti penilaian motivasi kerja siklus I semula $29 \%$ meningkat menjadi $86 \%$ artinya mengalami peningkatan sebesar $57 \%$, sedang penilaian kinerja guru pada siklus I awalnya 43\% meningkat menjadi $86 \%$ atau ada peningkatan $43 \%$.

\section{Saran}

Berdasarkan kesimpulan di atas, maka saran yang dapat direkomendasikan adalah sebagai berikut Bagi kepala sekolah: Agar selalu melaksanakan supervisi secara rutin dalam rangka meningkatkan motivasi dan kinerja guru. Supervisi kepala sekolah hendaknya dilaksanakan dengan perencanaan yang matang dan terencana sehingga pelaksanaan supervisi dapat dilaksanakan dengan efektif sehingga mampu mencapai tujuan supervisi yang telah direncanakan.

\section{Daftar Pustaka}

E.Mulyana. 2004. Manajemen Sumber Daya Manusia. Jakarta : Salemba Empat.

Gwyn. 2000. Model dan Teknik Penilaian. Jakarta : Bina Aksara.

Malayu Hasibuan. 2002. Pembinaan Profesi Guru dan Psikologi Pembinaan Personalia, Jakarta ; Departemen Pendidikan dan Kebudayaan.
M. Ngalim Purwanto. 2004. Managemen Sumber Daya Manusia. Yogyakarta : STIE YPKN.

Moh. Asa'ad. 2000. Psikologi Kerja. Jakarta: Departemen Pendidikan dan Kebudayaan.

Panji Anaroga. 2005. Motivasi Kerja Dalam Persepsi Pendidikan. Jakarta: Bina Aksara 